Даница М. Јеротијевић Тишма

Универзитет у Крагујевцу

Филолошко-уметнички факултет

Департман за англистику

https://doi.org/10.18485/ai_fonefonosj.2020.ch5

$811.111 ' 243$

$811.163 .41 ' 243$

\title{
ФАКТОРИ ПОВРАТНОГ ТРАНСФЕРА И ЮИХОВ УТИЦАЈ НА ВРЕМЕ НАСТУПА ЗВУЧНОСТИ БЕЗВУЧНИХ ПЛОЗИВА У СРПСКО-ЕНГЛЕСКОМ МЕЂУЈЕЗИЧКОМ СИСТЕМУ
}

Негативни трансфер из матерњег у страни језик представља један од фундаменталних фактора који утичу на усвајање гласова страног језика, што су показала бројна истраживања и у свету и код нас. С друге стране, повратни трансфер, тј. утицај страног језика на матерњи нешто је ређе истраживан, нарочито у српском научном контексту.

У раду испитујемо да ли и на који начин страни језик (у конкретном случају енглески) утиче на реализацију безвучних плозива у матерњем језику код српских ученика енглеског као страног језика. Акустичку анализу плозива базираћемо на анализи времена наступа звучности, као индикатору присуства или одсуства аспирације, и као једном од првих фонетских параметара који подлеже утицају гласова страног језика са којим говорник долази у контакт. Време наступа звучности представља време од праска до почетка периодичних вибрација пратећег вокала. Међутим, предмет рада није истраживање повратног трансфера per se, већ се пре свега фокусирамо на могуће факторе који предвиђају повратни трансфер, и то: време проведено на енглеском говорном подручју, 
године старости почетка учења и време проведено учећи енглески језик. Испитаници су одабрани на основу разлика у одабраним параметрима анализе, а сваки од њих снимљен је како изговара речи на енглеском и српском језику које садрже безвучне плозиве у иницијалној акцентованој позицији. Акустичка анализа добијених података извршена је у програму за акустичку анализу говора Praat и обрађена одговарајућим статистичким тестовима.

Резултати показују да је време проведено на енглеском говорном подручју један од кључних фактора повратног трансфера, као и време проведено учећи енглески језик, док се године старости почетка учења нису показале као статистички значајан предиктор повратног трансфера у нашем случају. Добијени резултати имају важне импликације за наставу енглеског као страног језика, као и за билингвизам и контактну лингвистику уопште.

Кључне речи: повратни трансфер, енглеско-српски, међујезик, ВОТ, безвучни плозиви

\section{1. Увод}

У уму билингвалног говорника, сматра се, оба фонетска система коегзистирају и међусобно утичу један на други (Флеги 1995; Павленко 2000; Гијон 2003). Иако је феномен интерференције матерњег језика обимно истражен у области усвајања другог/страног језика (Вајнрајх 1953; Ладо 1957; Флеги 2003), за обрнути процес, односно утицај страног језика на матерњи, може се рећи да су истраживања добила на интересовању тек у последњих двадесетак година (Павленко 2000). Повратни трансфер до сада је најбоље истражен на фонолошком нивоу, иако има доста студија у области лексике, семантике, морфосинтаксе и прагматике (Милер, 
Хулк 2001; Лауфер 2003; Сорас 2011), а доказан је како на сегменталном, тако на супрасегменталном нивоу. Повратни или обрнути трансфер није једини термин који се користи да означи утицај знања о страном језику на матерњи језик, већ се користе и други термини, нпр. бидирекционални трансфер, интерлингвални ефекти, међујезички утицаји/трансфер итд. (Кук 2003). Понекад се дати феномен поистовећује са атрицијом првог језика, јер се најчешће други језик сматра главним узроком атриције првог, тј. матерњег језика.

У релевантним студијама са билингвалним говорницима је показано да двосмерна интеракција матерњег и страног језика утиче на ментални лексикон (Хернандез et al. 1994), когнитивну обраду информација (Биалисток 2009), те говорну продукцију (Купске, Алвес 2016). Без обзира на релативно добру истраженост поменутог феномена на фонолошком нивоу пре свега у светском научном контексту, многа питања остају неразрешена, нарочито она везана за факторе који утичу на модификације гласова у матерњем језику, као и у ком смеру се дате модификације крећу, односно да ли теже сличности или разликовању од гласова страног језика. Такође, већина досадашњих студија рађена је са балансираним, тј. симетричним билингвалним говорницима у средини где се говори други/страни језик, а ређе у средини где је доминантан први/матерњи језик.

Имајући претходно наведено у виду, у раду се фокусирамо на факторе који могу предвидети повратни трансфер, и то на: време проведено на енглеском говорном подручју, године старости када је ученик отпочео учење страног језика и време проведено учећи енглески језик (изражено у сатима и подразумева количину инпута на дневном нивоу, формално и ван школе). Прецизније, у раду испитујемо да ли и на који начин 
страни језик утиче на реализацију безвучних плозива у матерњем језику код српских ученика енглеског као страног језика, и који су потенцијални фактори који обликују такво стање ствари.

\section{2. Повратни трансфер у истраживањима усвајања другог/страног језика}

У једном од првих значајнијих истраживања утицаја страног на матерњи језик, Павленко (2000: 179) наводи да се дати утицај огледа у неколико аспеката: а) лексичком позајмљивању елемената из J2 у J1, б) конвергенцији или стварању јединственог система који се разликује од оба језика, в) померању структура и вредности J1 како би се приближиле структурама из J2, г) реструктурирању или делимичном померању елемената из J2 у J1 при чему долази до одређених промена и супституција и 5) атрицији J1, тј. губљењу неких елемената из J1 под утицајем J2. Поменути аутор такође наводи да у перцепцији и продукцији времена наступа звучности матерњег језика долази до конвергенције и померања, што је релевантно за наше истраживање.

Истраживања међујезичке перцепције и продукције говора често се ослањају на један од три теоријска модела: Магнет матернег језика (Кул, Ајверсон 1995), Модел периептивне асимилације (Бест 1994) и Модел учень говора (Флеги 1995). Укратко, према првом од поменутих модела, магнети матерњег језика, тј. идеални представници фонетске категорије из J1, привлаче сличан глас из циљног језика ка јединственом прототипу из матерњег језика, а као последица тога јавља се немогућност разликовања сличних гласова у матерњем и страном језику. Према Моделу периептивне асимила- 
ицје говорници перципирају контрасте из страног језика или као говор или као „неговор”, при чему се они који се могу класификовати као говорни звуци даље деле на гласове који се могу или не могу асимиловати у фонетске категорије матерњег језика. Међутим, чини се да трећи модел најподробније приступа феномену релевантном за наш рад. Наиме, Модел учена говора на сличан начин посматра однос гласова матерњег језика са сличним гласовима страног језика, јер принцип класификације еквиваленције доводи до идентификовања сличних гласова из J2 са гласовима из J1, а самим тим и до изостанка њиховог међусобног разликовања. Док су прва два модела оријентисана ка перцепцији, потоњи модел предвиђа и развој продукције у међусистему. Према Флегијевој теорији $(1995,2007)$ не постоји критични период за усвајање фонолошког система страног језика, два фонетско-фонолошка система интерагују константно у уму билингвалног говорника и могу утицати међусобно један на други при чему је смер утицаја двосмеран. Фонетске категорије из J1 усвојене у детињству имају динамичну природу и могу се модификовати кроз асимилацију или дисимилацију када слични гласови из два језика дођу у контакт.

Иако у српским примењенолингвистичким истраживањима има доста студија која су показала значај утицаја матерњег на усвајање гласова страног језика (Марковић 2009; Пауновић 2011), колико нам је познато на основу претрага репозиторијума и библиотека, радова који се баве повратним трансфером готово да нема уопште. С тим у вези овај рад представља наставак нашег истраживања представљеног на конференцији Српски језик, книжевност, уметност октобра 2018. године на Филум-у, Крагујевац (Јеротијевић Тишма 2019). Истраживање је имало за циљ да утврди да ли 
формалност говорног стила утиче на присуство реверзибилне интерференције у енглеско-српском међујезичком систему. У раду су уочена три појавна облика повратног трансфера код српских студената англистике али се формалност говорног стила није показала као статистички значајан предиктор варијабилности, као ни квантитет вокала.

\section{3. Екстралингвистички фактори повратног трансфера}

Поред поменутих универзалних психолингвистичких фактора проистеклих из структурних разлика два језика, у које спада и класификација еквиваленције (Флеги 1987), поједини аутори наводе и неке ванјезичке факторе повратног трансфера. Међу њима, нарочито важни за утицај фонологије J2 на систем J1 јесу: а) почетна година усвајања, б) ниво флуентности на страном језику нарочито у спонтаном говору, в) интензивност изложености изворним говорницима страног језика у прошлости или садашњости, г) питање престижа страног језика, д) културна идентификација и ђ) способност фонетске имитације (Вилијамз 1980; Мејџор 1993). Други аутори наводе и факторе попут регионалних и етничких варијетета (Мејџор et al. 2007), фидбека (Шмит 2001), прозодијске варијабилности (Сомерс, Баркрофт 2007) и језичког искуства (Ливај, Стрејнџ 2008).

Ипак, у најдетаљније истражене факторе спадају година почетка учења другог/страног језика, дужина боравка у изворном говорном подручју и количина употребе матерњег језика (Мејџор 1992; Харада 2003; Гијон 2003; Бејкер, Трофимович 2005), те ћемо се сажето осврнути на њих. 
Студије које су проучавале утицај почетка учења (или у билингвалном контексту годину почетка становања у J2 говорном подручју) показале су да што се раније крене са учењем то ће утицај J2 на J1 бити снажнији. На примеру корејских говорника енглеског као страног језика који су у Америку дошли после дванаесте године живота показано је да је опште постигнуће по питању изговора било једнако постигнућу говорника који су живели у Сеулу (Јени-Комшиан et al. 2000). Говорници који су у Америку стигли као млађи су, пак, показали нижи ниво постигнућа од својих вршњака у Кореји, док је изговор енглеског био на вишем нивоу. Утицај дужине боравка у изворном говорном подручју истраживан је у студији са корејско-енглеским билингвалним говорницима, у којој су испитаници који су у енглеском говорном подручју провели просечно осам година модификовали изговор матерњих, тј. корејских вокала, док испитаници који су у истом подручју провели краћи период нису показивали сличне тенденције (Бејкер, Трофимович 2005). Време наступа звучности плозива америчких говорника који су живели у Бразилу одступало је од вредности монолингвалних америчких говорника (Мејџор 1992), а слична је ситуација и са португалским говорницима енглеског као страног језика у студији рађеној пет година касније (Сансир, Фаулер 1997). Такође, релевантна истраживања су показала да што је чешћа употреба матерњег језика, то ће у страном језику бити израженији страни нагласак и број грешака у изговору (Грожан 2001). Ипак, налази нису увек потврђивали овакве претпоставке. Наиме, у студији са мађарским говорницима показано је да имигранти који нису имали контакта са сопственом заједницом (а самим тим, претпоставља се, ни са својим матерњим језиком) нису одступали у изго- 
вору вокала од монолингвалних говорника мађарског језика (Мекроби 2003).

\section{4. Време наступа звучности}

\section{као индикатор повратног трансфера}

Време наступа звучности или време отпочињања тона (ВОТ) представља временски интервал између праска плозива и почетка периодичне вибрације предстојећег вокала (Лискер, Абрамсон 1964; Ладефогед 2001). Плозиви у језицима света показују тројаку вредност BOT: нулто BOT, када вибрација отпочиње готово истовремено са праском, тј. одмах након њега, позитивно BOT, које указује на аспирацију и представља одложену појаву вибрације након праска, и негативно ВОТ, код ког вибрација почиње пре праска и назива се пред-звучност. Услед одсуства аспирације у српском језику (Белић 1972), безвучни плозиви би требало да имају нулто BOT, док безвучни плозиви у превокалској акцентованој позицији имају позитивно ВОТ и одликује их аспирација, тј. додавање даха. Ваља напоменути да је ВОТ један од најподробније проучених фонетских параметара када је у питању усвајање гласова страног језика (Флеги 1987; Де Бот 2007), као и један од првих индикатора утицаја J2 на фонетски систем J1 (Антониу et al. 2010).

Током учења страног језика кореспондентне категорије из оба језика су уско повезане и ако се међу њима уоче разлике, напредак који ће уследити ка усвајању категорија из J2 резултираће утицајем J2 на J1 (Флеги 1995; Бест, Тајлер 2007). Потврду за бидирекционални утицај J1 и J2 нашао је још Флеги (1987) у студији ВОТ са енглеско-француским билингвалним говорницима. Обе групе проучаваних говорника, и 
они чији је матерњи језик енглески, и они чији је матерњи језик француски, нису продуковали алвеоларни безвучни плозив на исти начин као изворни говорник датог језика, већ су продуковали неку своју стопљену варијанту. Код јапанских говорника који су енглески почели да уче рано, уочено је да су безвучни плозиви који имају дуже BOT у енглеском, утицали на продужетак ВОТ код сличних гласова у матерњем језику (Харада 2003: 1085-1086). Код енглеских говорника који уче корејски као страни језик показано је дуже трајање ВОТ под утицајем виших вредности корејских аспированих плозива (Ченг 2012). У истраживању енглеских говорника шпанског као страног језика пак, само један од четворо проучаваних говорника показао је утицај страног језика на вредност ВОТ у матерњем језику за безвучне плозиве, док су остала три говорника показала бољу диференцијацију два језика. За звучне плозиве, диференцијација је била нешто мање успешна код свих говорника (Хафман, Шуман 2016: 8-9).

Српски и енглески фонолошки системи познају шест плозива, билабијално /p/ и /b/, алвеоларно (дентално у српском) /t/ и /d/, и веларно /k/ и /g/. /b d g/ класификујемо као звучне, док се /p t k/ одликују одсуством вибрације гласних жица, те су безвучни.

\section{5. Методологија}

\section{1. Циљ истраживања}

Циљ рада јесте испитати повратни трансфер у међујезичком систему опримерен вредностима времена наступа звучности безвучних плозива код српских ученика који уче енглески као страни језик. Прециз- 
није, у истраживању смо се фокусирали на потенцијалне ванлингвистичке факторе који предвиђају појаву повратног трансфера и то на: годину почетка учења страног језика, време проведено у енглеском говорном подручју и употребу енглеског језика (током формалног школског образовања и ван школе).

\section{2. Истраживачка питања}

Имајући у виду налазе релевантне литературе и постављене циљеве истраживања, рад смо базирали на следећим истраживачким питањима:

- Koје су вредности времена наступа звучности безвучних плозива у иницијалној акцентованој превокалској позицији у речима на српском и енглеском језику?

- Да ли вредности ВОТ у српско-енглеском међујезичком систему указују на повратни трансфер и да ли се продукција безвучних плозива може само једнострано посматрати?

- Може ли се на основу предложених фактора (године почетка учења страног језика, времена проведеног на енглеском говорном подручју и употребе енглеског језика) предвидети вредност ВОТ у српско-енглеском међујезичком систему када се контролишу фактори попут година старости и нивоа постигнућа?

\section{3. Испитаници}

У истраживању је учествовало 28 испитаника, 12 мушког и 16 женског пола. Популација испитаника бирана је у периоду од марта 2016. до јула 2018. године јер је било неопходно контролисати факторе година ста- 
рости (просек година=20.41 са распоном 20-21) и нивоа постигнућа (ниво Б2 Заједничког европског оквира за живе језике; дијагностичко тестирање вокабулара, граматике, слушања и читања извршено је пре почетка тестирања са свим испитаницима $\left.{ }^{1}\right)$. Испитаници су у тренутку тестирања били студенти различитих факултета у Београду и Крагујевцу, међу којима су: Електротехнички факултет, Факултет организационих наука, Правни факултет, Медицински факултет и Економски факултет. Сви испитаници су пре терцијарног образовања похађали гимназију - друштвено-језички и природно-математички смер. За прикупљање корпуса било је неопходно мало дуже времена јер је требало пронаћи сличну популацију испитаника али са разликама у дужини учења енглеског језика, боравка у иностранству и разликама у времену употребе енглеског језика. Такође је дати корпус ваљало балансирати на основу резултата тестирања продукције како би се обезбедили валидни подаци за статистичко тестирање. Испитаници су пре тестирања потписали сагласност о добровољном учешћу у истраживању. Детаљнији подаци о испитаницима налазе се у Табели 1. За сва три параметра анализе испитаници су били подељени у четири групе, што нам је олакшало касније кодирање у статистичкој обради података. Боравак на енглеском говорном подручју изражен је у месецима, а употреба енглеског језика у школи и ван ње на дневном нивоу изражена је у сатима. Податке о параметрима добили смо кратким интервјуом са испитаницима пре почетка тестирања.

1 Тестирање извршио аутор рада тестовима доступним на https:// www.examenglish.com/CEFR/b2.htm 
Табела 1. Популација испитаника и одабрани екстралингвистички фактори

\begin{tabular}{|l|l|l|}
\hline \multicolumn{1}{|c|}{ Почетак учења } & $\begin{array}{c}\text { Боравак на енглеском } \\
\text { говорном подручју }\end{array}$ & \multicolumn{1}{|c|}{$\begin{array}{c}\text { Употреба } \\
\text { енглеског језика }\end{array}$} \\
\hline 4 год. $\mathrm{N}=6$ & $0-3 \mathrm{mec} . \mathrm{N}=8$ & $0-1 \mathrm{~h} \mathrm{~N}=10$ \\
5 год. $\mathrm{N}=4$ & $3-9 \mathrm{Mec} . \mathrm{N}=5$ & $1-3 \mathrm{~h} \mathrm{~N}=2$ \\
6 год. $\mathrm{N}=7$ & $9-15 \mathrm{mec} . \mathrm{N}=4$ & $3-5 \mathrm{~h} \mathrm{~N}=7$ \\
7 год. $\mathrm{N}=11$ & $15-24 \mathrm{mec.} \mathrm{N}=11$ & Више од $5 \mathrm{~h} \mathrm{~N}=9$ \\
\hline
\end{tabular}

\section{4. Инструменти}

Инструмент за тестирање продукције била је листа одабраних речи са безвучним плозивима у иницијалној превокалској акцентованој позицији на српском и енглеском језику (по пет примера за сваки плозив у оба језика - укупно 30 примера). Дата позиција одабрана је као погодна за истраживање јер у енглеском језику у том окружењу долази до појаве аспирације, која је одсутна из српског језика, а у акцентованим позицијама се иначе наглашеније испољавају специфичне карактеристике гласова. Циљне речи налазиле су се унутар схематизованих реченица Say again. односно Реици onem. Методологија испитивања и коришћени инструменти засновани су на претходном истраживању сличне тематике (Антониу et al. 2011: 562). Испитаници су сваку реченицу читали три пута узастопно уз сугестију да читање буде што природније и опуштеније.

\section{5. Процедура и обрада корпуса}

Снимање продукције обављено је у више наврата (март, септембар, октобар 2016. јануар, март, јун, август 2017. и октобар и децембар 2018. године) дикта- 
фоном Olympus VN-8600РC висине семпловања 44.1 $\mathrm{kHz}$ и 16-битном конверзијом у WAV формату погодном за обраду у софтверу Praat, верзија 6.0.48 (Бурзма, Вејнинк 2019). Статистичка обрада спроведена у циљу анализе могућих предиктора међу задатим независним варијаблама урађена је у програму SPSS, верзија 23.0, коришћењем теста вишеструке линеарне регресије.

\section{6. Резултати и дискусија}

На основу резултата анализе корпуса испитанике смо поделили у четири групе у зависности од варијација у вредностима времена наступа звучности у енглеском (J2) и српском (J1) језику. Измерене просечне вредности ВОТ за сваки од безвучних плозива појединачно распоређени по групама испитаника налазе се у табелама 2 и 3.

Табела 2. Просечне вредности ВОТ у речима на енглеском језику (ms)

\begin{tabular}{|c|c|c|c|}
\hline Група & E-BOT $/ \mathbf{p} /$ & E-BOT $/ \mathbf{t} /$ & E-BOT /k/ \\
\hline I & 3.25 & 5.63 & 4.13 \\
$(\mathbf{N}=8)$ & $\mathrm{N}=40$ & $\mathrm{~N}=40$ & $\mathrm{~N}=40$ \\
\hline II & 48.38 & 49.5 & 64.38 \\
$(\mathbf{N}=\mathbf{8})$ & $\mathrm{N}=40$ & $\mathrm{~N}=40$ & $\mathrm{~N}=40$ \\
\hline III & 61.12 & 70.13 & 79.5 \\
$(\mathbf{N}=\mathbf{8})$ & $\mathrm{N}=40$ & $\mathrm{~N}=40$ & $\mathrm{~N}=40$ \\
\hline IV & 7.5 & 8.25 & 10.75 \\
$(\mathbf{N}=\mathbf{4})$ & $\mathrm{N}=20$ & $\mathrm{~N}=20$ & $\mathrm{~N}=20$ \\
\hline
\end{tabular}


Табела 3. Просечне вредности ВОТ у речима на српском језику (ms)

\begin{tabular}{|c|c|c|c|}
\hline Група & $\mathbf{C - B O T} / \mathbf{p} /$ & $\mathbf{C}-\mathrm{BOT} / \mathbf{t} /$ & $\mathbf{C}-\mathrm{BOT} / \mathbf{k} /$ \\
\hline I & 8.38 & 6.0 & 9.13 \\
$(\mathbf{N}=\mathbf{8})$ & $\mathrm{N}=40$ & $\mathrm{~N}=40$ & $\mathrm{~N}=40$ \\
\hline II & 7.13 & 8.38 & 11.13 \\
$(\mathbf{N}=\mathbf{8})$ & $\mathrm{N}=40$ & $\mathrm{~N}=40$ & $\mathrm{~N}=40$ \\
\hline III & 33.63 & 58.13 & 69.88 \\
$(\mathbf{N}=\mathbf{8})$ & $\mathrm{N}=40$ & $\mathrm{~N}=40$ & $\mathrm{~N}=40$ \\
\hline IV & 38.5 & 49.25 & 43.0 \\
$(\mathbf{N}=\mathbf{4})$ & $\mathrm{N}=20$ & $\mathrm{~N}=20$ & $\mathrm{~N}=20$ \\
\hline
\end{tabular}

Прва група испитаника најбоље илуструје добро познати утицај матерњег језика на страни, односно интерференцију матерњег језика или језички трансфер. Наиме, вредности ВОТ код ове групе говорника изузетно су ниске у српском језику, али се слична ситуација осликава и у енглеском језику, односно вокал почиње одмах након праска без интервала фрикације између који би указивао на аспирацију. Спектрограми продукције говорника из прве групе испитаника са слике 1 илуструју управо веома мали интервал између праска и почетка вокала у речима на оба језика. Такође је на спектрограмима једва видљив траг фрикације који би указао на евентуалну аспирацију. 
Фактори повратног трансфера и њихов утицај на време... 123

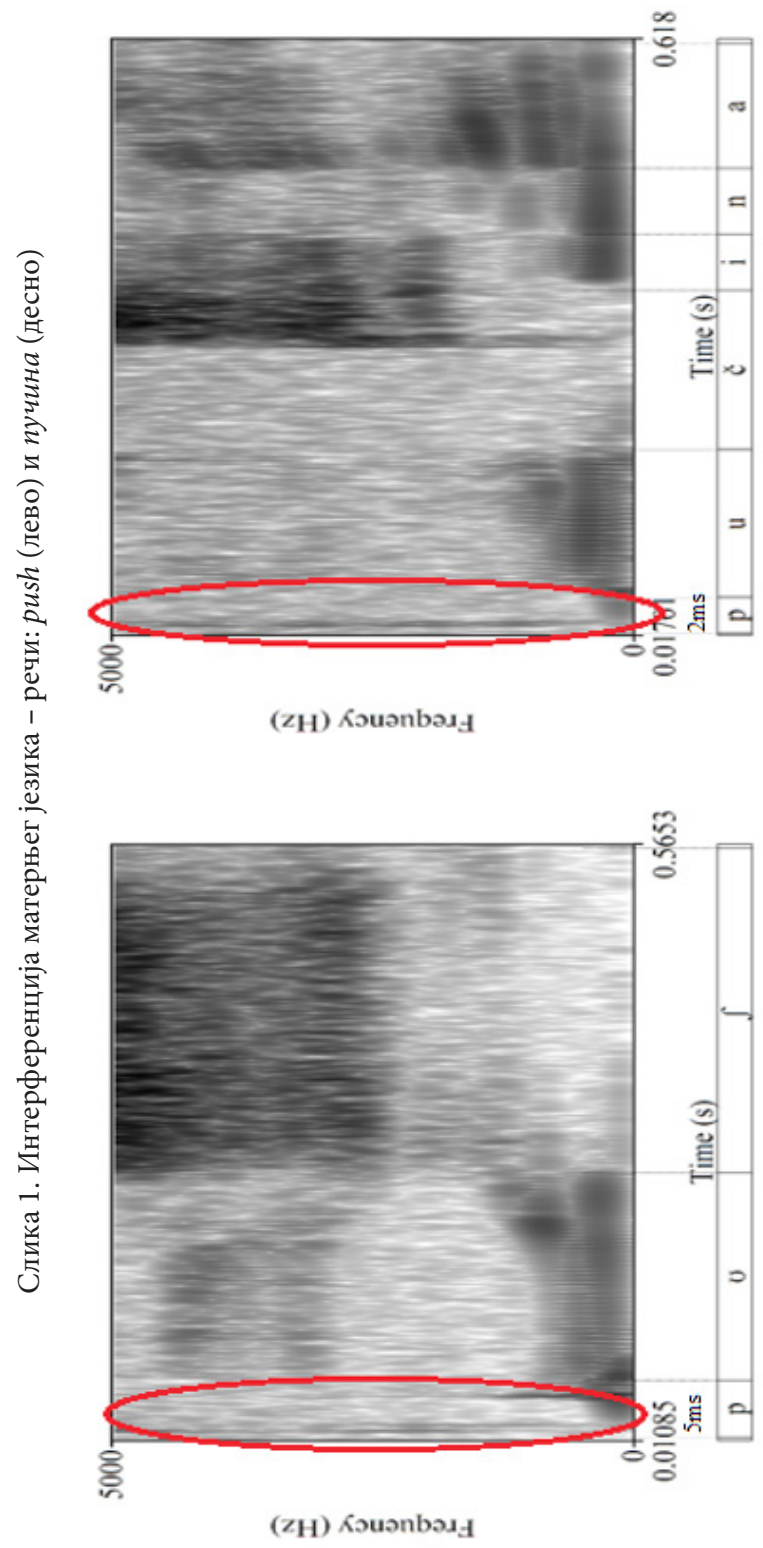


У другу групу испитаника сместили смо оне говорнике који су у процесу усвајања страног језика успели да изворни и страни глас одвоје на две различите категорије, тј. успели су да уоче не само фонолошке већ и фонетске разлике између плозива у српском и енглеском језику. Из табела 2 и 3 видимо да су вредности ВОТ у енглеском језику знатно више од оних у српском, што значи да енглеске безвучне плозиве продукују уз додатак даха, а српске не. Слика 2 садржи два спектрограма говорника из друге групе, где се на слици лево у енглеској речи иза праска осликава турбулентни шум који указује на аспирацију, док је на слици десно дати шум једва видљив и вокал почиње готово одмах након праска. Затамњења на другом спектрограму производ су вокалских транзиција и позадинске буке пре него шума аспирације који би се осликао на вишим фреквенцијама. 
Фактори повратног трансфера и њихов утицај на време... 125

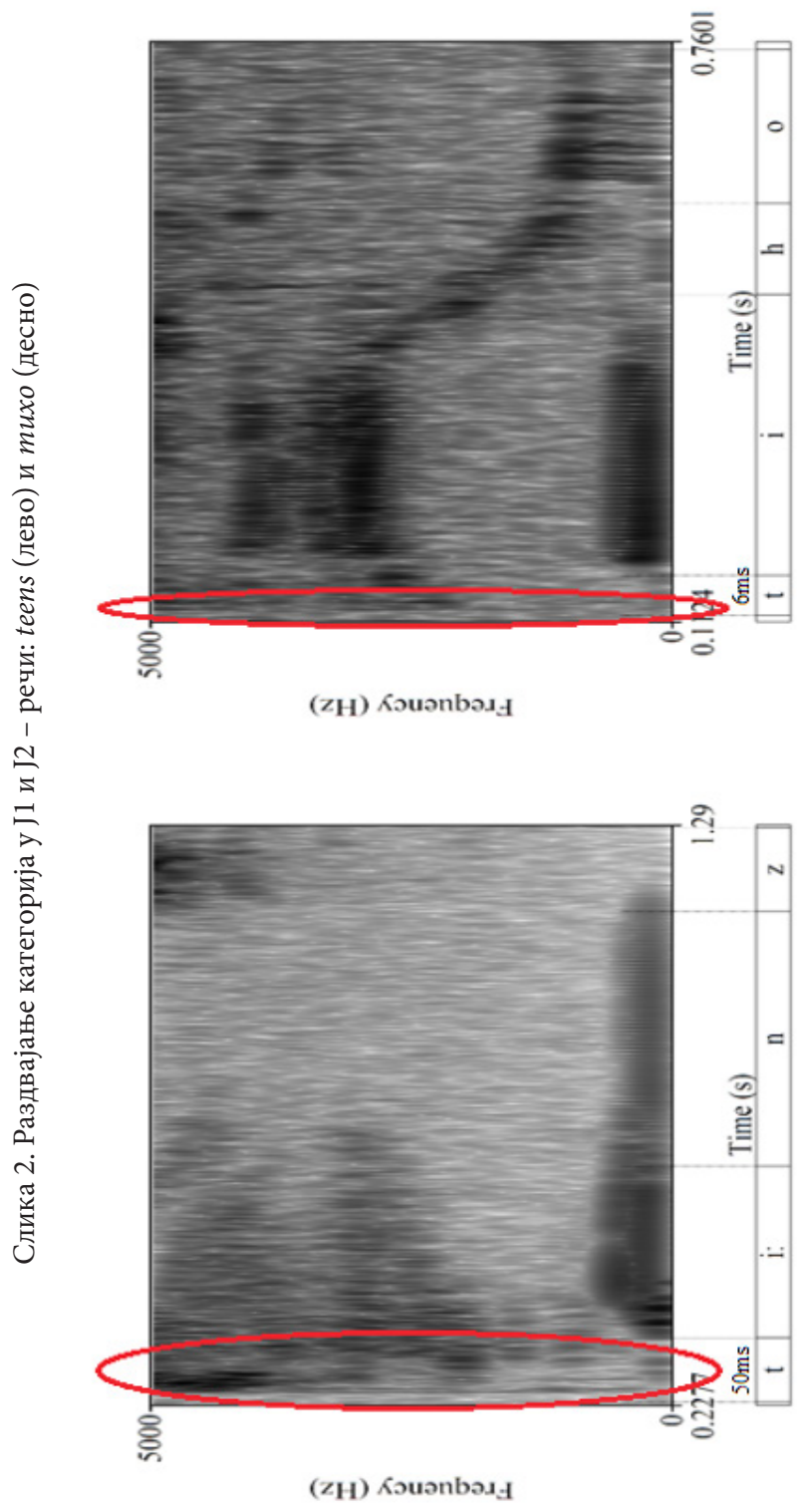


У трећу групу говорника спадају они чији изговор потенцијално указује на присуство повратног трансфера, односно продужетак вредности ВОТ и у српском и у енглеском језику, што можемо видети и из табела 2 и 3 , али и на спектрограмима са слике 3. И у речи на енглеском и у речи на српском видимо присуство турбулентног шума у интервалу веларног безвучног плозива и транзиције у наредни вокал задњег реда. На изговор гласова матерњег језика ове групе говорника утицај је извршио страни језик у одређеној мери, а о потенцијалним предикторима говорићемо у наставку рада. 


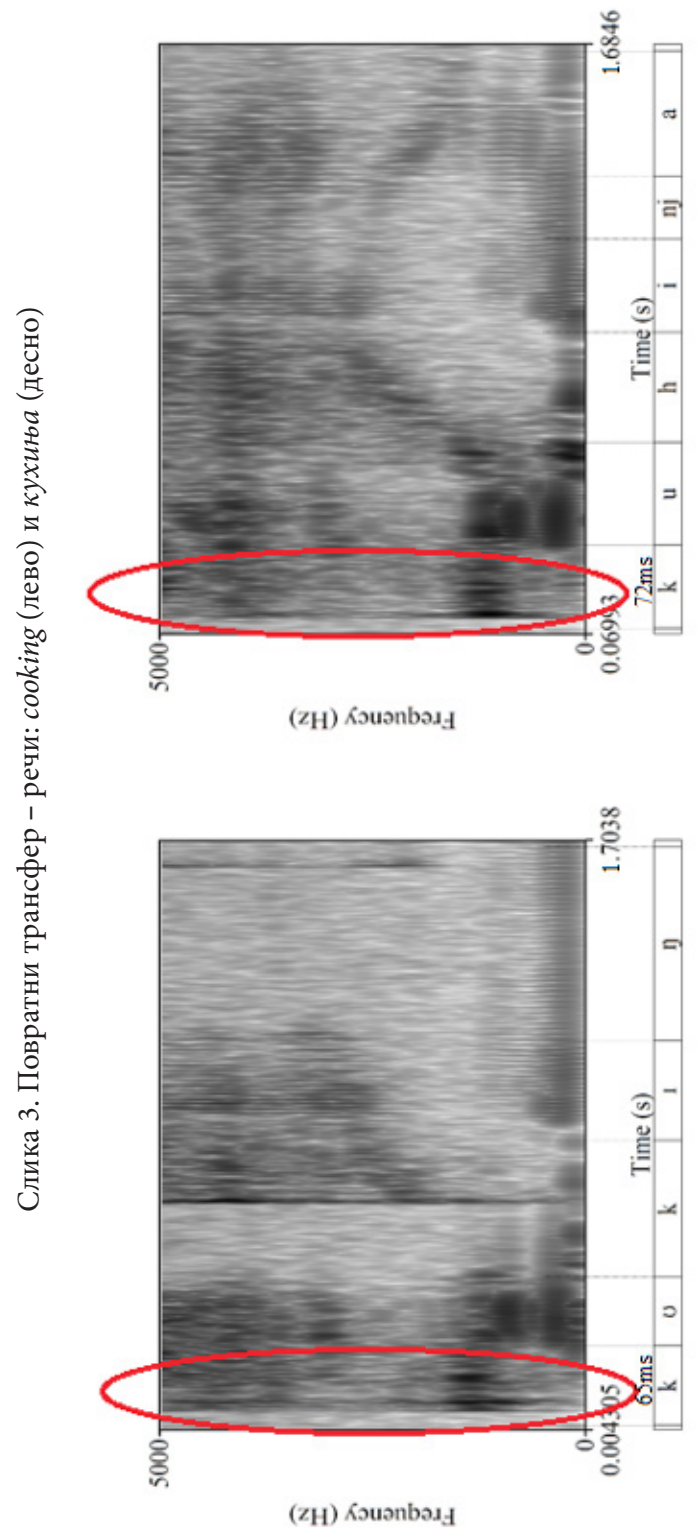


Нарочито занимљива јесте четврта група говорника која показује помало необично и недоследно понашање када је у питању изговор безвучних плозива. На основу резултата мерења у табелама 2 и 3 , видимо релативно високе вредности ВОТ у речима на српском језику, али ниске вредности ВОТ у речима на енглеском језику. Слика 4 илуструје ову ситуацију спектрограмима речи у оба језика. У корпусу нема много говорника са оваквом продукцијом, али смо сматрали да су вредни помена јер показују необичне карактеристике изговора. Можемо претпоставити да је до оваквих резултата дошло из неколико разлога. Овакав изговор можемо приписати индивидуалним варијацијама говорника, и афективним факторима попут збуњености и нервозе због испитивања. Такође, могуће је да су дати говорници у процесу усвајања помешали карактеристике оба језика, али нису успели јасно да их диференцирају, па је услед хиперкорекције дошло до ове својеврсне замене утицаја оба језика. На неки начин овде можемо говорити о истовременом трансферу и повратном трансфеpy, јер оба језика негативно утичу на вредности ВОТ и процесуирање информација. Овакви случајеви само додатно потврђују претпоставке о сложеној природи међујезика и испреплетаности бројних фактора у процесу усвајања гласова страног језика. Због специфичности изговора ове групе испитаника неопходно је продубити анализу у неком од будућих истраживања како би се подробније анализирали сви могући фактори за такво стање ствари. 
Фактори повратног трансфера и њихов утицај на време... 129

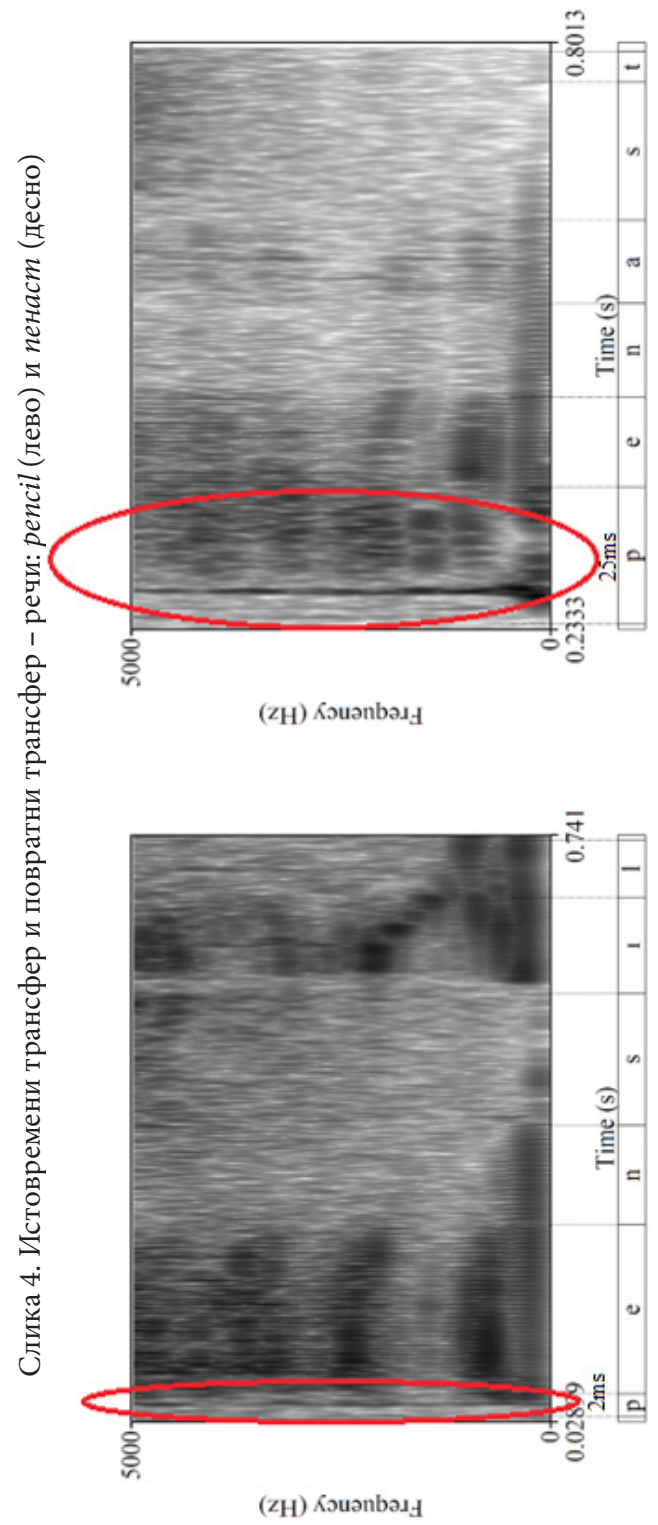


Како бисмо проверили да ли било који од предиктора може објаснити варијабилност вредности ВОТ у српском и у енглеском језику спровели смо тест вишеструке линеарне регресије. Имајући у виду сложеност поступка поменутог статистичког теста, пре његовог спровођења, уверили смо се да су испоштоване све претпоставке које дати статистички модел захтева да буду испуњени како би се успешно интерпретирали резултати. Пре свега водили смо рачуна о типу зависне (континуалне) и независних варијабли, као и о њиховом међусобном линеарном односу. Независност резидуала мерили смо Дурбин-Вотсоновим тестом чија је вредност 2.175 и уверили се да су релативно нормално дистрибуирани. Податке одликује хомоскедастичност, али не и мултиколинеарност нити има аутлајера и тачака јаког утицаја. Резултати статистичке анализе налазе се у табелама 4 и 5.

Табела 4. Резултати статистичке анализе по факторима за енглески језик

\begin{tabular}{|c|c|c|}
\hline Почетак учења & $\begin{array}{c}\text { Боравак на } \\
\text { енглеском говорном } \\
\text { подручју }\end{array}$ & $\begin{array}{c}\text { Употреба енгле- } \\
\text { ског језика }\end{array}$ \\
\hline \multicolumn{3}{|c|}{ ANOVA $\mathrm{F}=32.924 \mathrm{p}=0.0001$} \\
$\mathrm{R}^{2}=0.780$
\end{tabular}

Табела 4. Резултати статистичке анализе по факторима за српски језик

\begin{tabular}{|c|c|c|}
\hline Почетак учења & $\begin{array}{c}\text { Боравак на енгле- } \\
\text { ском говорном } \\
\text { подручјy }\end{array}$ & $\begin{array}{c}\text { Употреба енгле- } \\
\text { ског језика }\end{array}$ \\
\hline \multicolumn{3}{|c|}{ ANOVA $\mathrm{F}=4.695 \mathrm{p}=0.010$} \\
$\mathrm{R}^{2}=0.291$ \\
\hline $\mathrm{s}=1.608 \mathrm{p}=0.120$ & $\mathrm{t}=2.761 \mathrm{p}=0.001$ & $\mathrm{t}=2.238 \mathrm{p}=0.034$ \\
\hline
\end{tabular}


На основу анализе видимо да у оба случаја и за ВОТ у енглеском $\left(\mathrm{F}=32.924 \mathrm{p}=0.0001 \mathrm{R}^{2}=0.780\right)$ и за ВОТ у српском $\left(\mathrm{F}=4.695 \mathrm{p}=0.010 \mathrm{R}^{2}=0.291\right)$ независне варијабле статистички значајно предвиђају варијације у вредностима $(\mathrm{p}<0.05)$. Као статистички значајни предиктори показали су се дужина боравка у енглеском говорном подручју и количина инпута, односно време проведено учећи енглески језик у школи и ван ње за оба језика. Почетак учења енглеског језика статистички је значајан предиктор само за варијабилност вредности ВОТ у енглеском језику, док то не важи за српски језик. Нестандардизовани бета коефицијенти детаљније нам показују кретања варијабилности.

Наиме, када је у питању вредност ВОТ за речи у енглеском језику, за сваку годину ранијег почетка учења вредност ВОТ се повећава за 6.866, што би се могло интерпретирати тако што бисмо могли претпоставити да ученици који раније крену са учењем перципирају дуже трајање времена наступа звучности, односно уочавају присуство аспирације. Прецизније, што се раније крене са учењем то су већи изгледи за уочавање фонетских карактеристика гласова страног језика, у овом случају безвучних плозива. Са друге стране, варијабилност ВОТ у речима на српском језику не може се статистички значајно предвидети на основу година старости почетка учења страног језика ( $\mathrm{p}=0.120)$, односно на појаву варијабилности утичу неки додатни фактори. Што се тиче другог фактора, тј. независне варијабле, дужине боравка у енглеском говорном подручју, за енглески језик уочавамо да за сваки месец проведен дуже у иностранству вредност ВОТ се повећава за 5.808 , а у српском за 11.872. Овакви резултати, наравно, узети с резервом због специфичности методолошког дизајна, одабраног узорка и броја испитаника, указују на чињеницу да дужи боравак у енглеском говорном подручју 
доводи до продужетка ВОТ у енглеском, тј. перципирању ВОТ као дужег у односу на матерњи језик, али и до продужетка BOT у српском код неких говорника, што упућује на појаву повратног трансфера односно утицај контакта са енглеским језиком у изворној средини на фине промене фонетских карактеристика гласова у матерњем, тј. српском језику. Трећи фактор предвиђања, време проведено учећи енглески језик, односно количина инпута на енглеском језику којем су испитаници били изложени на свакодневном нивоу како током часова у школи тако и код куће, на вредности ВОТ у енглеском утицала је тако што се за сваки сат повећања инпута вредност ВОТ повећава за 12.564, а у српском језику за 7.880. Поново, дакле, контакт са циљним језиком доводи до раздвајања категорија али и до повратног трансфера. Имајући претходно наведено у виду, може се закључити да пре свега дужина боравка и контакт са изворним говорницима, као и количина инпута, доводи до варијабилности вредности ВОТ у страном и матерњем језику.

\section{7.Закључак}

Након увода и кратког осврта на досадашња разматрања повратног трансфера, у раду су представљени резултати спроведеног емпиријског истраживања на корпусу сачињеном од 28 испитаника са контролисаним факторима година старости и нивоом постигнућа, и разликама у одабраним параметрима чији смо утицај желели да испитамо - дужина боравка на енглеском говорном подручју, почетак учења страног језика и време проведено учећи енглески језик.

На основу анализе спектрограма и мерења просечних вредности времена наступа звучности, одабрани 
узорак испитаника поделили смо у четири различите групе у зависности од карактеристика изговора безвучних плозива. Пратећи делимично предлоге претходног истраживања (Антониу et al. 2011) групе испитаника биле су подељене на следећи начин: у првој су били они чије је ВОТ показивао утицај матерњег језика, односно био је готово једнаких вредности у српским и енглеским речима; у другој су били испитаници који су успели да диференцирају матерње и стране фонетско-фонолошке категорије; у трећој су били „представници“ повратног трансфера, односно ВОТ је имало више вредности у речима на оба језика; а у четвртој групи нашла се посебна група чији је изговор испољавао неочекиване карактеристике, у смислу да је ВОТ било ниско у енглеском, а необично високо у српском, што смо интерпретирали као истовремени утицај оба језика и збуњеност у процесуирању информација у међујезичком систему. Из добијених података и одабране популације испитаника можемо закључити да време наступа звучности заиста може бити индикатор повратног трансфера, односно да може назначити утицај страног језика на матерњи, што је у складу са претходним налазима (Флеги 1987; Харада 2003; Ченг 2012).

Осим констатовања да у вредностима ВОТ видимо утицај J2 на J1, желели смо да испитамо могу ли одређени екстралингвистички фактори предвидети варијабилност вредности ВОТ, а самим тим и повратни трансфер. Наиме, од одабраних независних варијабли испоставило се да боравак на изворном говорном подручју и количина инпута статистички значајно објашњавају варијације вредности ВОТ, док је почетак учења био статистички значајан само за BOT у речима на енглеском језику. Из тога смо закључили да контакт са изворним говорницима и страним језиком има пресудан утицај на варијације ВОТ али и на поја- 
ву повратног трансфера, пре свега тако што, како расте време проведено у контакту са изворним говорницима и страним језиком, веће су шансе за појаву повратног трансфера, али и диференцирања категорија у J1 и J2. До сличних закључака аутори су долазили и раније (Грожан 2001; Бејкер, Трофимович 2005).

Резултати истраживања имају важне импликације за наставу у српском контексту учења енглеског као страног језика, јер указују на важност сталне употребе страног језика и у школи и ван ње. Наставници би требало да подстичу употребу страног језика и ван оквира формалног образовања. Такође, резултати указују на сложеност и испреплетаност фактора који обликују изговор и свест билингвалног говорника.

Као потенцијалне потешкоће у реализацији истраживања морамо потцртати захтевност и дуготрајност одабира популације испитаника, а као ограничења дизајн тестирања, јер би ваљало истражити и безвучне плозиве у другим контекстима како би се добио бољи увид у вредности релевантних фонетских параметара. Због околности у којима су снимани говорници није увек било лако контролисати спољашње факторе и буку што је допринело генерисању не сасвим јасних слика на спектрограмима. Будућа истраживања би требало фокусирати на већи број испитаника, посебно на четврту групу испитаника која је у нашем истраживању показала мешани утицај језика у продукцији безвучних плозива.

\section{ЛИТЕРАТУРА}

Антониу et al. 2010: Antoniou, M., Best, C. T., Tyler, M. D., Kroos, C. Language context elicits native-like stop voicing in 
early bilinguals' productions in both L1 and L2. Journal of Phonetics, 38, 640-653. [PubMed: 21743759]

Антониу et al. 2011: Antoniou, M., Best, C. T., Tyler, M. D., Kroos, C. Inter-language interference in VOT production by L2-dominant bilinguals: Asymmetries in phonetic codeswitching. Journal of Phonetics, 39(4), 558-570. doi:10.1016/j. wocn.2011.03.001

Бејкер, Трофимович 2005: Baker, W., Trofimovich, P. Interaction of native- and second-language vowel system(s) in early and late bilinguals. Language and Speech, 48, 1-27.

Белић 1972: Belić, A. Osnovi istorije srpskohrvatskog jezika I Fonetika. Beograd: Naučna knjiga.

Бест 1994: Best, С. The emergence of native-language phonological influences in infants: A perceptual assimilation model. In J. Goodman and H. Nusbaum (Eds.), The Development of Speech Perception: The Transition from Speech Sounds to Spoken Words. (pp. 167-224). Cambridge, MA: The MIT Press.

Бест, Тајлер 2007: Best, C., Tyler, M. (Non-native and second-language speech perception: Commonalities and complementarities. In M.J. Munro and O.-S. Bohn (Eds.), Second language speech learning: The role of language experience in speech perception and production. (pp. 13-34). Amsterdam; Philadelphia: John Benjamins.

Биалисток 2009: Bialystok, E. Metalinguistic aspects of bilingual processing. Annual Review of Applied Linguistics. v. 21, n. 1, 169-181.

Бурзма, Вејнинк 2019: Boersma, B., Weenink, D. Praat: Doing phonetics by computer (Version 6.0.48) [Computer program]. Доступно на: http://www.praat.org/. Преузето: 15. 4. 2019.

Bајнрајх 1953: Weinreich, U. Languages in contact. Linguistic Circle of New York.

Вилијамз 1980: Williams, L. Phonetic variation as a function of second-language learning. In G. Yeni-Komshian, J. Kavanagh, \& C. Ferguson (Eds.), Child Phonology: Volume 2. Perception (pp. 185-215). New York: Academic Press.

Гијон 2003: Guion, S.G. The vowel systems of Quichua-Spanish bilinguals: Age of acquisition effects on the mutual influence of the first and second languages. Phonetica, 60, 98-128. 
Грожан 2001: Grosjean, F. The bilingual's language modes. In: NICOL, Janet (Org.). One Mind, Two Languages: Bilingual Language Processing. Blackwell, 1-22.

Де Бот 2007: De Bot, K. Dynamic Systems Theory, life span development and language attrition. In: B. Köpke, M. S. Schmid, M. Keijzer, \& S. Dostert (Eds.), Language attrition: Theoretical perspectives (pp. 53-68). Amsterdam: John Benjamins Publishing Company.

Јени-Комшиан et al. 2000: Yeni-Komshian, G., Flege, J. E., Liu,

S. (2000). Pronunciation proficiency in first and second languages of Korean-English bilinguals. Bilingualism: Language and Cognition, 3, 131-149.

Јеротијевић Тишма 2019: Jerotijević Tišma, D. Reverzibilna interferencija na primeru vremena nastupa zvučnosti kod srpskih učenika engleskog kao stranog jezika. Zbornik radova sa XIII međunarodnog naučnog skupa Srpski jezik, književnost, umetnost (26-27. oktobar 2018), FILUM, Univerzitet u Kragujevcu, 249-263.

Кук 2003: Cook, V. (Ed.). Effects of the second language on the first. Clevedon, UK: Multilingual Matters.

Кул, Ајверсон 1995: Kuhl, P., Iverson, P. Linguistic experience and the perceptual magnet effect, In W. Strange (Ed.), Speech Perception and Linguistic Experience: Issues in Cross-language Research (pp. 121-154). Baltimore: York.

Купске, Алвес 2016: Kupske, F., Alves, U. A fala de imigrantes brasileiros de primeira geração em Londres como evidência empírica para a língua como um Sistema Adaptativo Complexo. ReVEL, v. 14, n. 27, 173-203.

Ладефогед 2001: Ladefoged, P. Vowels and Consonants: An Introduction to the Sounds of Languages. Oxford: Blackwells. Ладо 1957: Lado, R. Linguistics across cultures. Ann Arbor: University of Michigan Press.

Лayфep 2003: Laufer, B. The Influence of L2 on L1 Collocational Knowledge and on L1 Lexical Diversity in Free Written Expression. In Cook, V. (ed.), Effects of the Second Language on the First (pp. 19-31). Clevedon: Multilingual Matters Publishing. 
Ливај, Стрејнџ 2008: Levy, E. S., Strange, W. Perception of French vowels by American English adults with and without French language experience, Journal of Phonetics, 36, 141-157.

Лискер, Абрамсон 1964: Lisker, L., Abramson, A.S. A crosslanguage study of voicing in initial stops: Acoustical measurements. Word, 20, 384-422.

Марковић 2009: Marković, M. Different Strategies in Acquiring L2 Vowels: The Production of High English Vowels /i:, I, u:, $\mathrm{v} /$ by Native Speakers of Serbian. In Čubrović, B. and T. Paunović (eds), Ta(l)king English Phonetics Across Frontiers. Cambridge: Cambridge Scholars Publishing, 3-18.

Mejџop 1992: Major, R.C. Losing English as a first language. The Modern Language Journal, 76, 190-208.

Mejџop 1993: Major, R. Sociolinguistic factors in loss and acquisition of phonology. In: K. Hyltenstam, \& A. Viberg (Eds.), Progression and regression in language: Sociocultural, neuropsychological and linguistic perspectives (pp. 463-478). Cambridge: CUP.

Мејџор, Баптиста 2007: Major, R., Baptista, B. First language attrition in foreign accent detection. In: Watkings, Michael, Rauber, Andreia, Baptista, Barbara (Org.). Recent research in second language phonetics/phonology: Perception and production. Newcastle Upon Tyne: Cambridge Scholars, 256-269.

Мекроби 2003: McRobbie, Z. Sound change in progress.an acoustic study of vowel variation in the speech of Hungarians in Vancouver, British Columbia. In Z. McRobbie \& C.So (Eds.) Proceedings of the $13^{\text {th }}$ Conference of the Finno-Ugric Studies Association of Canada (pp.83-91). Burnaby: Simon Fraser University.

Милер, Хулк 2001: Müller, N., Hulk, A. Crosslinguistic influence in bilingual language acquisition: Italian and French as recipient languages. Bilingualism: Language and Cognition, 4, pp. 1-21.

Павленко 2000: Pavlenko, A. L2 influence on L1 in late bilingualism. Issues in Applied Linguistics, 11(2), 175-205.

Пауновић 2011: Paunović, T. Sounds Serbian? Acoustic properties of Serbian EFL students' speech. In Kitis, E., N. 
Lavidas, N. Topintzi \& T. Tsangalidis (Eds.) Selected Papers from the $19^{\text {th }}$ International Symposium on Theoretical and Applied Linguistics, April 3-5 2009, 357-369. Thessaloniki: Aristotle University, School of English, Department of Theoretical \& Applied Linguistics.

Сансир, Фаулер 1997: Sancier. M., L., Fowler, С. A. Gestural drift in a bilingual speaker of Brazilian Portuguese and English. Journal of Phonetics, v. 27, n. 4, pp. 421-436.

Сомерс, Баркрофт 2007: Sommers, M., Barcroft, J. An integrated account of the effects of acoustic variability in first language and second language: Evidence from amplitude, fundamental frequency, and speaking rate variability. Applied Psycholinguistics, 28(2), 231-249.

Copac 2011: Sorace, A. Pinning down the concept of interface. Linguistic Approaches to Bilingualism, 1, 1-33.

Флеги 1987: Flege, J. The production of "new" and "similar" phones in a foreign language: Evidence for the effect of equivalence classification. Journal of Phonetics, 15, 47-65.

Флеги 1995: Flege, J. E. Second language speech learning theory, findings and problems. In W. Strange (Ed.) Speech Perception and Linguistic Experience: Issues in Cross Language Research (pp. 233-277). Baltimore, MD: York Press.

Флеги 2003: Flege, J. Assessing Constraints on Second-Language Segmental Production and Perception. In (eds.) A. Meyer and N. Schiller, Phonetics and Phonology in Language Comprehension and Production, Differences and Similarities. (pp. 319-355). Berlin: Mouton de Gruyter.

Харада 2003: Harada, T. L2 influence on L1 speech in the production of VOT. In M. J. Solé, D. Recasens, \& J. Romero, Proceedings of the 15th International Congress of Phonetic Sciences (ICPhS) (pp. 1085-1088) Adelaide, Australia: Causal Productions.

Хафман, Шуман 2015: Huffman, M. K., Schuhmann, K. S. Effect of early L2 learning on L1 stop voicing. Proceedings of Meetings on Acoustics, 23, 060007; doi: 10.1121/2.0000168

Хернандез et al. 1994: Hernandez, A., Bates, E., Avila, L. On-line sentence interpretation in Spanish-English bilinguals: What does it mean to be "in between"? Applied Psycholinguistics, v. $15,417-446$. 
Ченг 2012: Chang, C.B. Rapid and multifaceted effects of secondlanguage learning on first-language speech production. Journal of Phonetics, 40, p249-268.

Шмит 2001: Schmidt, R. W. Attention. In: P. Robinson (Ed.), Cognition and second language instruction (pp. 3-32). New York: Cambridge University Press.

\title{
Danica M. Jerotijević Tišma
}

\author{
FACTORS OF REVERSE INTERFERENCE \\ AND THEIR IMPACT ON VOICELESS PLOSIVES' \\ VOT IN SERBIAN-ENGLISH INTERLANGUAGE
}

\section{Summary}

Negative mother tongue interference represents one of the fundamental factors affecting sound acquisition in an L2, which was confirmed by a substantial amount of research in the world as well as in the Serbian scientific context. On the other hand, reverse interference, i.e. the effect of L 2 on $\mathrm{L} 1$ has undergone less frequent investigation especially among Serbian scholars.

The present paper analyzes whether and to what extent a foreign language (English in our case) affects the realization of voiceless plosives in L1 considering the chosen sample of Serbian EFL learners. Acoustic analysis was based on the analysis of VOT as an indicator of the presence or absence of aspiration, and as one of the first parameters being affected by the sounds of a foreign language the speaker comes in contact with. VOT represents the interval from the release burst to the beginning of periodic vibrations of the following vowel. Our focus is not on VOT values and reverse interference only, yet we likewise aim at investigating the potential factors predicting reverse interference, especially the following: length of residence in an English-speaking country, age of onset of learning the L2 and the amount of formal and extracurricular input. The participants were selected based on the 
differences in the chosen characteristics, and they were recorded pronouncing a word list with target tokens (voiceless plosives) in initial accented position both in Serbian and English. Acoustic analysis was performed using Praat followed by adequate statistical testing.

The results showed that the length of residence was a key factor predicting the reverse transfer, as well as the amount of input, while the age of onset did not turn out to be a statistically significant predictor of reverse interference in our particular case. The obtained results have important pedagogical implications for EFL teaching, as well as for bilingualism and contact linguistics in general.

Keywords: reverse interference, Serbian EFL learners, interlanguage, VOT, voiceless plosives 